\title{
Recovery and purification of cellulolytic enzymes from Aspergillus fumigatus CCT 7873 using an aqueous two-phase micellar system
}

Sérgio Dantas de Oliveira Júnior, Carlos Eduardo de Araújo Padilha, Estefani Alves de Asevedo, Gorete Ribeiro de Macedo and Everaldo Silvino dos Santos ${ }^{*}$ (i)

\begin{abstract}
Purpose: In this study, an aqueous two-phase micellar system (ATPMS), formed by the non-ionic surfactant Triton $X-114$, was used to investigate the partitioning of cellulolytic enzymes produced by the filamentous fungus Aspergillus fumigatus CCT 7873.

Methods: Performance of the ATPMS on the partitioning of CMCase (activity on carboxymethyl cellulose) and FPase (activity on filter paper) was investigated by varying the temperature $\left(35,40,45,50,55,60\right.$, and $65^{\circ} \mathrm{C}$ ), enzyme crude extract concentration (20,40,60, and 80\% w/w), and Triton X-114 concentration (2, 4, 6, and 8\% w/ w) and by adding different inorganic salts $\left(\mathrm{NaCl}, \mathrm{CaCl}_{2}, \mathrm{MgSO}_{4}\right.$, and $\left.\mathrm{MnSO}_{4}\right)$ in the system.

Results: An ATPMS formed with 8\% (w/W) Triton X-114 and 40\% (w/W) enzymatic crude extract at a system temperature of $55^{\circ} \mathrm{C}$ was most favorable for partitioning the tested enzymes. Under these conditions, a purification factor for CMCase and FPase of 10.89 and 0.65 was reached, respectively. The addition of inorganic salts changed the distribution of enzymes. Of these, $\mathrm{CaCl}_{2}$ contributed to a higher distribution coefficient (50.0), whereas for FPase, the presence of $\mathrm{MnSO}_{4}$ in the system improved the purification factor to 3.94.

Conclusion: The highest values obtained for the yield and purification factors demonstrate that ATPMS is an interesting option for recovering and purifying cellulolytic enzymes.
\end{abstract}

Keywords: Aspergillus fumigatus, Cellulases, Micelles, Liquid-liquid extraction, Downstream processing

\section{Introduction}

Brazil is a large producer of agro-industrial products, and thus it generates a lot of lignocellulosic residues (Machado et al. 2010). In general, these residues are rich in cellulose, hemicelluloses, and lignin. Additionally, they are a cheap and abundant (Castilho et al. 2000). Cellulose can be used to produce value-added products, such as second-generation ethanol. In this case, pretreatment

\footnotetext{
*Correspondence: everaldo@eq.ufrn.br

Laboratory of Biochemical Engineering - Chemical Engineering Department, Federal University of Rio Grande do Norte (UFRN), Campus Universitário, Natal, Rio Grande no Norte, Brazil
}

and fermentation processes are followed by a distillation step in order to obtain the product (Sousa et al. 2009). Also, depending on the microorganism and the type of fermentation used, important products such as enzymes and pigments can be obtained mainly by using solidstate fermentation (SSF). Using SSF, microorganism growth is carried out in the absence or near absence of free water, occurring on a solid surface (Ruiz et al. 2012). In general, this approach leads to a more concentrated extract, i.e., the metabolites produced are more concentrated, and also has a lower energy demand compared to the classical submerged fermentation. However,

(c) The Author(s). 2020 Open Access This article is licensed under a Creative Commons Attribution 4.0 International License, which permits use, sharing, adaptation, distribution and reproduction in any medium or format, as long as you give appropriate credit to the original author(s) and the source, provide a link to the Creative Commons licence, and indicate if changes were made. The images or other third party material in this article are included in the article's Creative Commons licence, unless indicated otherwise in a credit line to the material. If material is not included in the article's Creative Commons licence and your intended use is not permitted by statutory regulation or exceeds the permitted use, you will need to obtain permission directly from the copyright holder. To view a copy of this licence, visit http://creativecommons.org/licenses/by/4.0/. 
process variables, such as temperature and $\mathrm{pH}$, are more difficult to control when SSF is used.

Among the enzymes that can be produced using lignocellulosic residues, cellulases play a key role in products such as textile, chemicals, and animal feed. Cellulases consist of a group of endo- and exo-enzymes acting synergistically in order to convert cellulose into glucose (Gan et al. 2003; Chandra Kalra et al. 2010). On the other hand, large-scale enzyme production, as well as the production of other biomolecules, depends on the techniques used during the purification protocol. Obviously, the final use dictates the purification degree needed for the biomolecule. Additionally, downstream processing represents up to $80 \%$ of the total cost of the process (McCreath et al. 1995, Sousa Júnior et al. 2016). Thus, integrative techniques play a key role in downstream processing. One such technique involves aqueous two-phase micellar systems (ATPMS). This is a liquidliquid extraction technique that uses surfactants with a concentration higher than the critical micelle concentration (CMC), i.e., a concentration at which the surfactant does not occur as a monomer but rather as a micellestructure. Additionally, the formation of micelles is related to the equilibrium of intermolecular forces, including Van der Waals, hydrophobic, steric, and electrostatic ones (Liu et al. 1998). Therefore, once these selfassembling aggregates are achieved, a biphasic system is built (Liu et al. 1996), which can be exploited for biomolecule separation/purification. In this case, this system is advantageous since it is able to maintain the activity of the biomolecules, i.e., it is environmentally friendly. The migration of the biomolecules depends on their miscibility to the micelle-rich phase or to the micelle-poor phase (Ramelmeier et al. 1991). The ATPMS is based on the use of a surfactant in order to form two immiscible phases, a bottom phase that is rich in micelles and an upper phase that is poor in micelles (for the systems shown here). The formation of the two phases is usually implemented by changing the temperature, also known the cloud point, which is used to determine the coexistence curve (Rangel-yagui et al. 2004). In these systems, the temperature, along with parameters such as $\mathrm{pH}$, surfactant concentration, and the presence of salts, can induce the two-phase formation (Ooi et al. 2011). The main surfactant used is a nonionic one, such as Triton X-114 (Wang et al. 2013).

In this context, due to the importance of reducing the costs of downstream processing by exploiting integrative techniques, this study investigated the partitioning behavior of cellulases using an ATPMS formed by a nonionic surfactant (Triton X-114), inorganic salts, and crude extract at different concentrations. The coexistence curves, i.e., the formation of a cloud point as a function of the surfactant concentration, were obtained for every condition assayed. There are few studies in the literature that have applied ATPMS to recover and purify cellulolytic enzymes, such as CMCase (activity on carboxymethyl cellulose) and FPase (activity on filter paper).

\section{Material and methods Chemicals}

Bovine serum albumin (BSA), the nonionic surfactant Triton X-114, and carboxymethyl cellulose (CMC) were acquired from Sigma-Aldrich (Ohio, USA). A low molecular protein weight marker was acquired from GE healthcare (Sweden). The inorganic salts $\mathrm{CaCl}_{2}, \mathrm{MgSO}_{4}$, $\mathrm{MnSO}_{4}$, and $\mathrm{NaCl}$ were of analytical grade. Ultrapure water was obtained from a Milli-Q system.

\section{Sugar cane bagasse}

Sugar cane bagasse was acquired from Estivas sugar plants (Rio Grande do Norte-Brazil). After an initial screening, the bagasse was washed and dried using a tray dryer at $70{ }^{\circ} \mathrm{C}$ for 5 days. Then, it was milled (Willye, TE-680, Tecnal, São Paulo/Brazil) and sifted through a 20-mesh sieve. The main composition of the sugar cane bagasse, in percentages, consisted of cellulose (39.25 \pm 5.49), hemicellulose (25.20 \pm 1.13$)$, and lignin (18.82 \pm $0.01)$. The material used in this study was the same material reported by Oliveira et al. (2018).

\section{Microorganism and inoculum}

The filamentous fungus Aspergillus fumigatus, isolated from coconut shells (identified and registered at the André Tosello Foundation (Campinas/Brazil) as CCT 7873), was used to produce the cellulolytic enzymes and was kept in the Biochemical Engineering Laboratory of the Federal University of Rio Grande do Norte (Natal/ Brazil). For the inoculum, A. fumigatus CCT 7873 was transferred to potato dextrose agar (PDA) medium and incubated at $30^{\circ} \mathrm{C}$ for 5 days. Spore propagation to SSF was carried out by transferring $1.0 \mathrm{~mL}$ of Tween 80 $(0.2 \% \mathrm{v} / \mathrm{v})$ containing microorganisms from the Petri plate and incubating it in a Biochemical Oxygen Demand (BOD) machine (Model: TE-394/I, TECNAL-São Paulo/Brazil) at $30{ }^{\circ} \mathrm{C}$ for 7 days. The spore concentration was determined using a Neubauer countingchamber. The spore concentration used as an inoculum for the SSF experiments was $1 \times 10^{6}$ spores/gram of solid medium (Coelho et al. 2001).

\section{Semi-solid fermentation (SSF) and crude enzymatic extract}

The cellulolytic crude enzymatic extract was produced by the filamentous fungus A. fumigatus CCT 7873 by SSF using sugarcane bagasse as a substrate $(50 \%$ moisture with water activity of 0.973 ) and adding nutrient 
salting solution ( $\mathrm{pH} 4.5)$ according to Urbanszki et al. (2000). After $120 \mathrm{~h}$ of cultivation, the crude extract was harvested from the flasks. In this case, $35 \mathrm{~mL}$ acetate buffer ( $200 \mathrm{mM}, \mathrm{pH} 5.0$ ) was added to $5.0 \mathrm{~g}$ fermented medium using a glass rod. Next, enzyme extraction was carried out using acetate buffer under shaking (Tecnal, TE-421, São Paulo/Brazil) for $30 \mathrm{~min}$ at $160 \mathrm{rpm}$ and 30 ${ }^{\circ} \mathrm{C}$ (Coelho et al. 2001). Then, the extract was filtered and centrifuged for $10 \mathrm{~min}$ at $2000 \mathrm{rpm}$ and $20^{\circ} \mathrm{C}$. The supernatant containing the cellulolytic enzymatic extract was stored and used in the ATPMS.

\section{Cloud point determination}

The ATPMS cloud point was determined by visual identification, i.e., by observing the system conditions in which the first turvation occurred. The determination of the cloud point for the solution containing the surfactant was carried out as described by Watanabe and Tanaka (1978). It consisted of the visual identification of the temperature at which a given surfactant solution with a known concentration became cloudy. The mixtures were added to conical tubes and transferred to a water bath. The temperature was incremented by $0.1{ }^{\circ} \mathrm{C}$ stepwise every $20 \mathrm{~min}$.

\section{Aqueous two-phase micellar system}

The cellulolytic enzymes were partitioned using an ATPMS composed of Triton X-114 at concentrations of $2,4,6$, and $8 \%(\mathrm{w} / \mathrm{w})$. Additionally, we investigated the impact of temperature $\left(35,40,45,50,55,60\right.$, and $\left.65^{\circ} \mathrm{C}\right)$, extract concentration $(20,40,60$, and $80 \%)$, and inorganic salts $\left(\mathrm{NaCl}, \mathrm{CaCl}_{2}, \mathrm{MgSO}_{4}\right.$, and $\left.\mathrm{MnSO}_{4}\right)$, all at
$5.0 \%(\mathrm{w} / \mathrm{w})$, on the partitioning of the cellulolytic enzymes using ATPMS. The $\mathrm{pH}$ of the system was kept at 5.0. For the formation of a micellar system, a given quantity of Triton X-114, enzyme extract, and salt was added to a centrifugation tube $(15 \mathrm{~mL})$ for a final mass of 5.0 g. Deionized water was used to complement the final mass. The tube was shaken for $1 \mathrm{~min}$ and phase separation occurred by settling it for $3 \mathrm{~h}$ in a water bath at a given temperature. The phase volume (top and bottom) was measured, and sampling of the phases was performed for quantification of enzymatic activity (CMCase and FPase) and total protein, which permitted the calculation of the partition coefficient, yield, and the purification factor for the cellulases.

\section{Partition coefficient $(K)$, yield $(Y)$, and purification factor} (PF)

The partition coefficient $(K)$ for the enzymes in the ATPMS was calculated according to Eq. (1):

$$
K=\frac{A_{t}}{A_{b}}
$$

where $A_{t}$ is the enzymatic activity in the top phase (micelle-poor phase) and $A_{b}$ is the enzymatic activity in the bottom phase (micelle-rich phase).

The enzyme yield $(Y)$ in the top phase was obtained as shown by Eq. (2):

$$
Y=\left(\frac{A_{t} V_{t}}{A_{i} V_{i}}\right) \times 100
$$

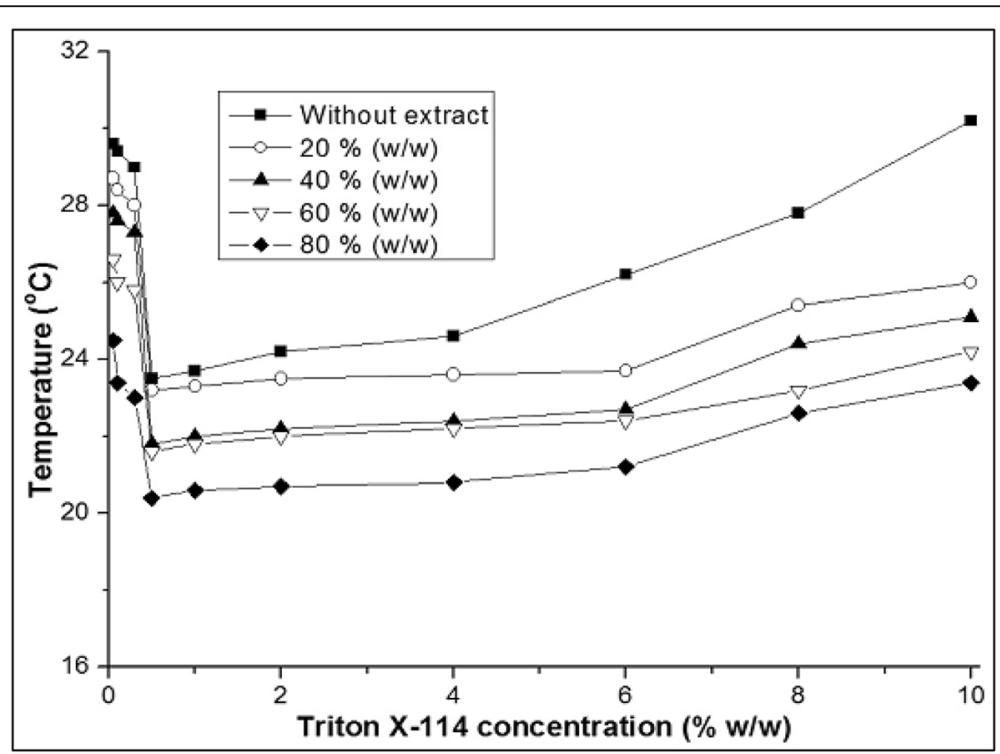

Fig. 1 Coexistence curves for the aqueous two-phase micellar system (ATPMS) with varying enzymatic extract (0 to $80 \%$ (W/W)) and Triton X-114 $(2,4,6,8$, and $10 \%(w / w))$ concentrations at different temperatures 
where $V_{t}$ and $V_{i}$ are the top and initial volumes, respectively.

The purification factor was estimated with regard to the specific activity as described in Eq. (3):

$$
P F=\frac{A_{t} / C_{t}}{A_{i} / C_{i}}
$$

where $C_{t}$ and $C i$ are the total protein at top phase and the initial concentration in the fermented broth, respectively.

\section{Cellulase activity (CMCase and FPase) and total protein quantification}

The CMCase activity was determined by adding $0.5 \mathrm{~mL}$ of enzyme extract to $0.5 \mathrm{~mL}$ of CMC $4 \%(\mathrm{w} / \mathrm{w})$ in citrate buffer (50.0 mM, pH 4.8), according to Ghose (1987).
The enzymatic reaction was performed for $10 \mathrm{~min}$ at 50 ${ }^{\circ} \mathrm{C}$. The mixture was heated in a water bath for $10 \mathrm{~min}$ at a temperature adjusted to $50{ }^{\circ} \mathrm{C}$. The reaction was stopped by boiling and the formation of reducing sugars was analyzed in a spectrophotometer (Thermo Spectronic) using the 3,5-dinitrosalicylic acid method (Miller 1959) with D-glucose as standard. A unit (U) of CMCase was defined as the enzyme quantity necessary to produce $1.0 \mu \mathrm{mol}$ of D-glucose per minute under the assay conditions. The quantification was performed in duplicate and the results shown are the means.

The FPase activity was quantified by adding $0.5 \mathrm{~mL}$ of the enzymatic extract to $1.0 \mathrm{~mL}$ of citrate buffer $(50.0$ $\mathrm{mM}, \mathrm{pH} 4.8$ ) containing filter paper strip (Whatman No. 1) $(1.0 \mathrm{~cm} \times 6.0 \mathrm{~cm})$ according to Ghose (1987). The mixture was heated in a water bath for $60 \mathrm{~min}$ and the formation of reducing sugars was analyzed in a

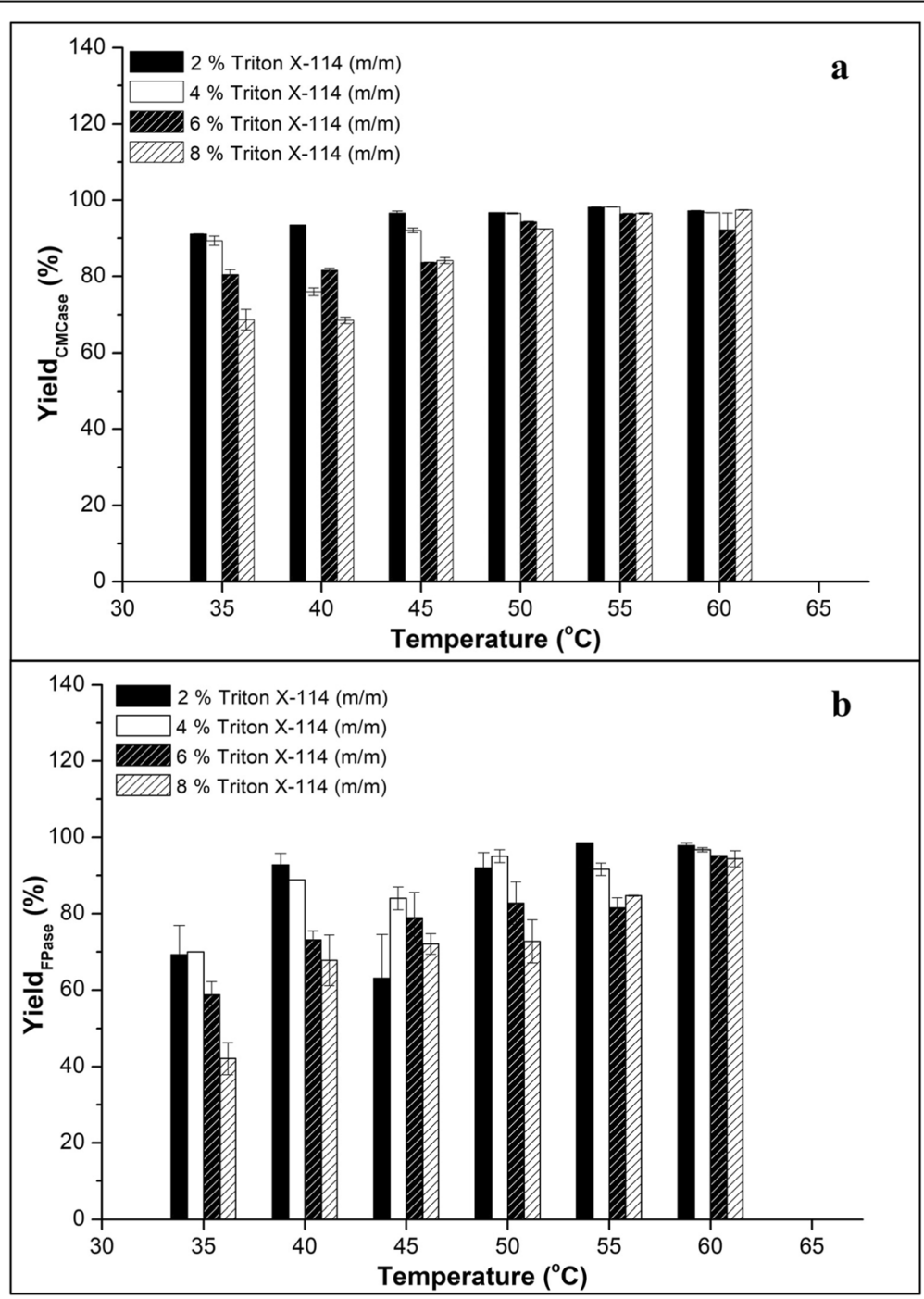

Fig. 2 CMCase (a) and FPase (b) yields obtained during partitioning in the ATPMS using different Triton X-114 concentrations and changing the temperature from 35 to $65^{\circ} \mathrm{C}$ at $40 \%$ enzymatic extract concentration 
spectrophotometer (Thermo Spectronic) using the 3,5dinitrosalicylic acid method (Miller 1959), with Dglucose as a standard. A unit (U) of FPase was defined as the enzyme quantity necessary to produce $1.0 \mu \mathrm{mol}$ of D-glucose per minute under the assay conditions. The quantification was performed in duplicate and results shown are the means.

The total protein content was determined at $595 \mathrm{~nm}$ according to Bradford (1976). Bovine serum albumin (Sigma-Aldrich, Ohio, USA) was used as a standard. The quantification was performed in triplicate and the results shown are the means.

\section{Polyacrylamide gel electrophoresis (SDS-PAGE)}

Electrophoresis using denaturing condition (SDS-PAGE) was performed using $10 \%(\mathrm{w} / \mathrm{v})$ acrylamide according to Laemmli (1970). The protein bands were stained using silver nitrate. A low molecular protein weight marker (GE healthcare, Sweden) was used in order to estimate the molecular mass of the proteins.

\section{Zymogram}

A zymogram was obtained by adapting the method proposed by Takenaka et al. (1999). In summary, the samples were dialyzed overnight and concentrated $(1.0 \mathrm{mg} /$ $\mathrm{mL})$, and were then submitted to a PAGE by adding $0.2 \% \mathrm{CMC}$ to a gel prepared with Tris- $\mathrm{HCl}(1.5 \mathrm{M}, \mathrm{pH}$ 8.8) for $3 \mathrm{~h}$ at $4{ }^{\circ} \mathrm{C}$.

In order to observe the cellulolytic activity, the gel was shaken and incubated using sodium citrate buffer (50.0 $\mathrm{mM}, \mathrm{pH} 4.8$ ) at $50{ }^{\circ} \mathrm{C}$ for $1 \mathrm{~h}$. Next, the gel was washed using distilled water, and was then immersed and shaken in congo red dye solution $(0.1 \% \mathrm{v} / \mathrm{v})$ for $20 \mathrm{~min}$ and

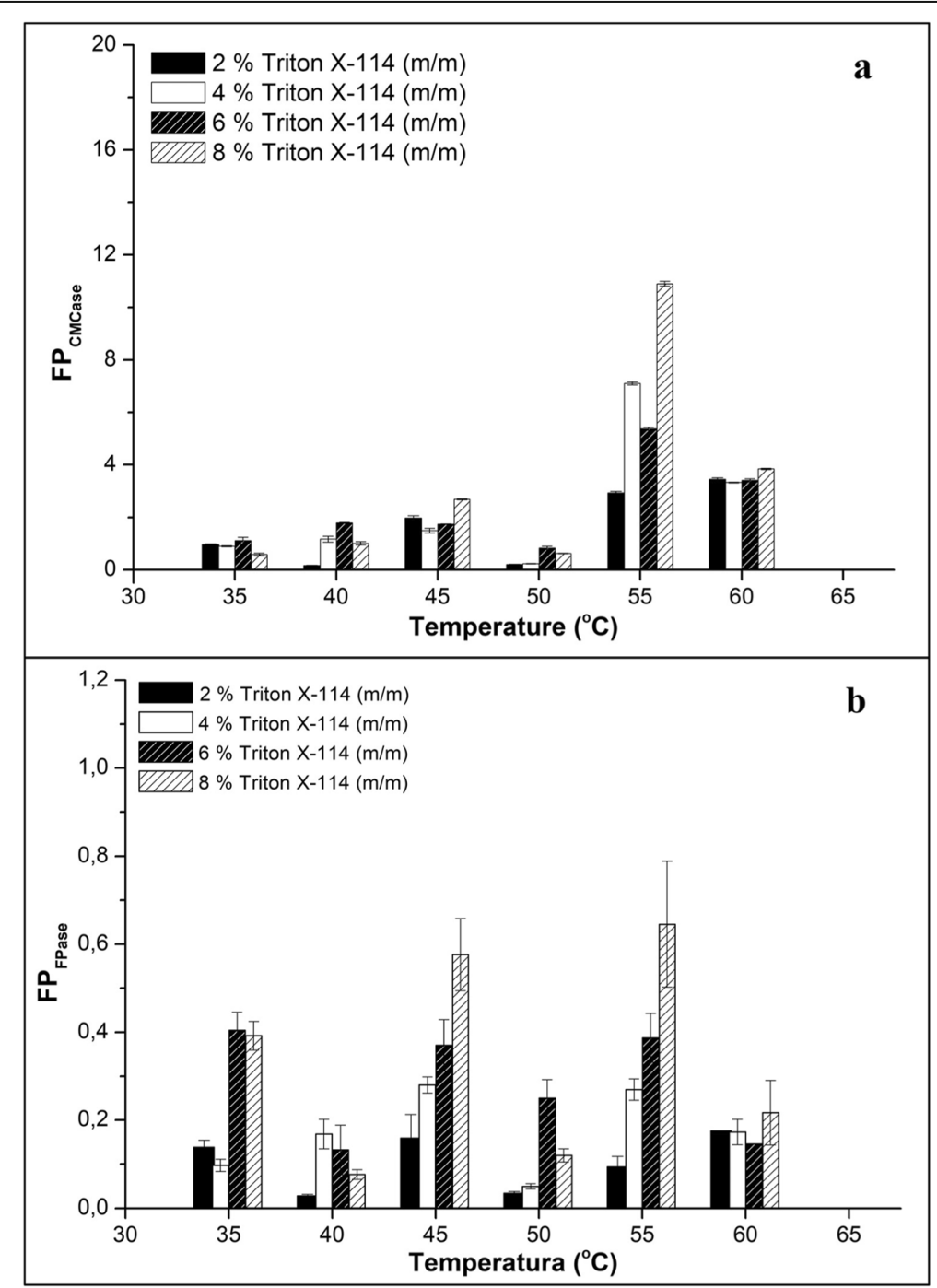

Fig. 3 Purification factor for CMCase (a) and FPase (b) obtained during partitioning in the ATPMS using different Triton X-114 concentrations and changing the temperature from 35 to $65^{\circ} \mathrm{C}$ at $40 \%$ enzymatic extract concentration 
washed with $1.0 \mathrm{M} \mathrm{NaCl}$ until the bands appeared, confirming the cellulolytic activity.

\section{Results}

\section{Triton X-114 coexistence curves}

The quantification of coexistence curves is crucial for understanding the ATPMS. The coexistence curve delimits the single phase from the biphasic region in the diagram. Figure 1 shows the coexistence curves formed at different temperatures, changing both the enzymatic extract content as well as the Triton X-114 concentration.

Our results clearly demonstrate that the coexistence curve is influenced by the extract content. A higher extract concentration led to a lower critical temperature $\left(\mathrm{T}_{\mathrm{c}}\right)$ for the ATPMS.
Influence of Triton X-114 concentration and temperature on cellulolytic enzyme partitioning

The influence of Triton X-114 on the cellulase yield (CMCase and FPase) was assayed by keeping the enzymatic extract at $40 \%(\mathrm{w} / \mathrm{w})$ and changing the Triton X-114 concentration and the temperature, as shown in Fig. 2. For the crude extract, the initial conditions were $0.70 \mathrm{IU} / \mathrm{mL}, 0.11$ $\mathrm{IU} / \mathrm{mL}$, and $0.64 \mathrm{mg} / \mathrm{mL}$ for CMCase, FPase, and total protein, respectively. It was observed that for enzyme CMCase, the highest yields were obtained at $60{ }^{\circ} \mathrm{C}$, regardless of the surfactant concentration in the system (Fig. 2a). The highest value for the partition coefficient $(K)$ for CMCase was 9.33 (see supplemental Table S1), obtained at $60{ }^{\circ} \mathrm{C}$ when the Triton X-114 concentration was $8 \%(\mathrm{w} / \mathrm{w})$.

Figure 3 shows the purification factor for the two classes of enzymes assayed. The results revealed that the purification process for CMCase is favorable when the

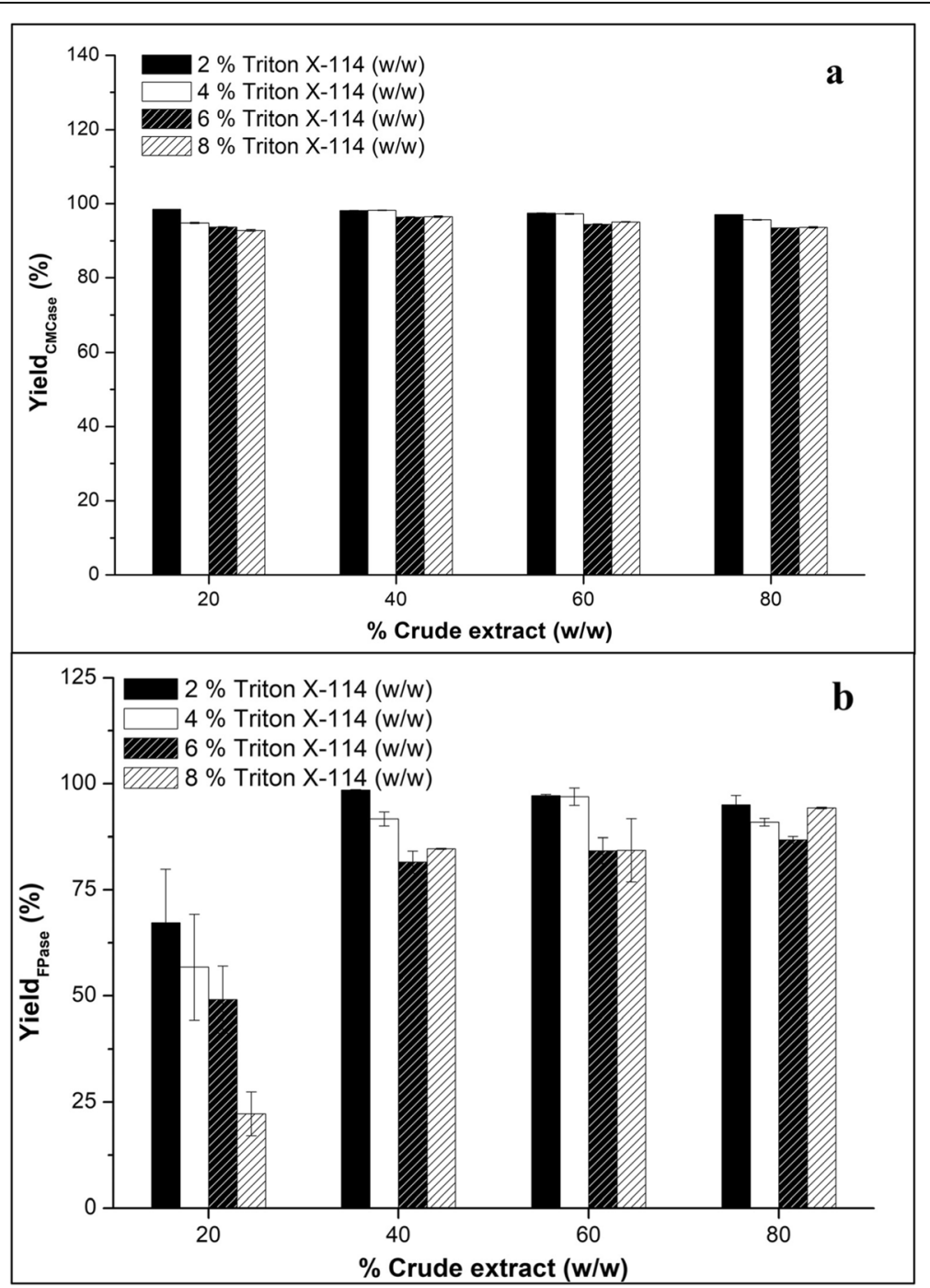

Fig. 4 CMCase (a) and FPase (b) yields obtained during partitioning in the ATPMS using different Triton X-114 concentrations and changing the crude extract concentration at $55^{\circ} \mathrm{C}$. 
ATPMS is operated at $5{ }^{\circ} \mathrm{C}$ with a Triton $\mathrm{X}-114$ concentration of $8 \%(\mathrm{w} / \mathrm{w})$. In this case, a PF of 10.89 was reached for CMCase.

For FPase, even though a temperature of $55^{\circ} \mathrm{C}$ using a Triton X-114 concentration of $8 \%(\mathrm{w} / \mathrm{w})$ showed a higher PF, the PF value was still lower than 1.0. This revealed that these enzymes prefer the micelle-rich phase. Similar to the CMCase, the FPase also showed an increase on the PF due to the increase of the temperature of the system with the same Triton X-114 concentration $(8 \%(\mathrm{w} / \mathrm{w}))$. In this case, the increase on the PF was an approximately 8.1-fold increase, as shown in Fig. 3.

Influence of the Triton X-114 concentration and crude extract on cellulolytic enzyme partitioning

The influence of Triton X-114 on the cellulase yield (CMCase and FPase) was assayed by changing the Triton
$\mathrm{X}-114$ concentration as well as the crude extract concentration while keeping the temperature at $55{ }^{\circ} \mathrm{C}$, since this temperature produced the best results for $K$ and $\mathrm{PF}$ for both enzymes. Figure 4 a shows a yield value of $92 \%$ for the CMCase regardless of the crude extract concentration used in the system. However, the use of the $20 \%(\mathrm{w} / \mathrm{w})$ crude extract strongly reduced the yield for the FPase.

Regarding the purification factor for both CMCase and FPase, a higher crude extract of $40 \%(\mathrm{w} / \mathrm{w})$ was favorable, mainly for a Triton X-114 concentration of $8 \%(\mathrm{w} / \mathrm{w})$, as shown in Fig. 5 and in the Supplemental Table S2. The PF obtained for CMCase was again higher than that for FPase.

Influence of the Triton X-114 concentration and inorganic salts on cellulolytic enzyme partitioning

The salt type and content played a key role in the partitioning of biomolecules using the ATPMS. Therefore, in

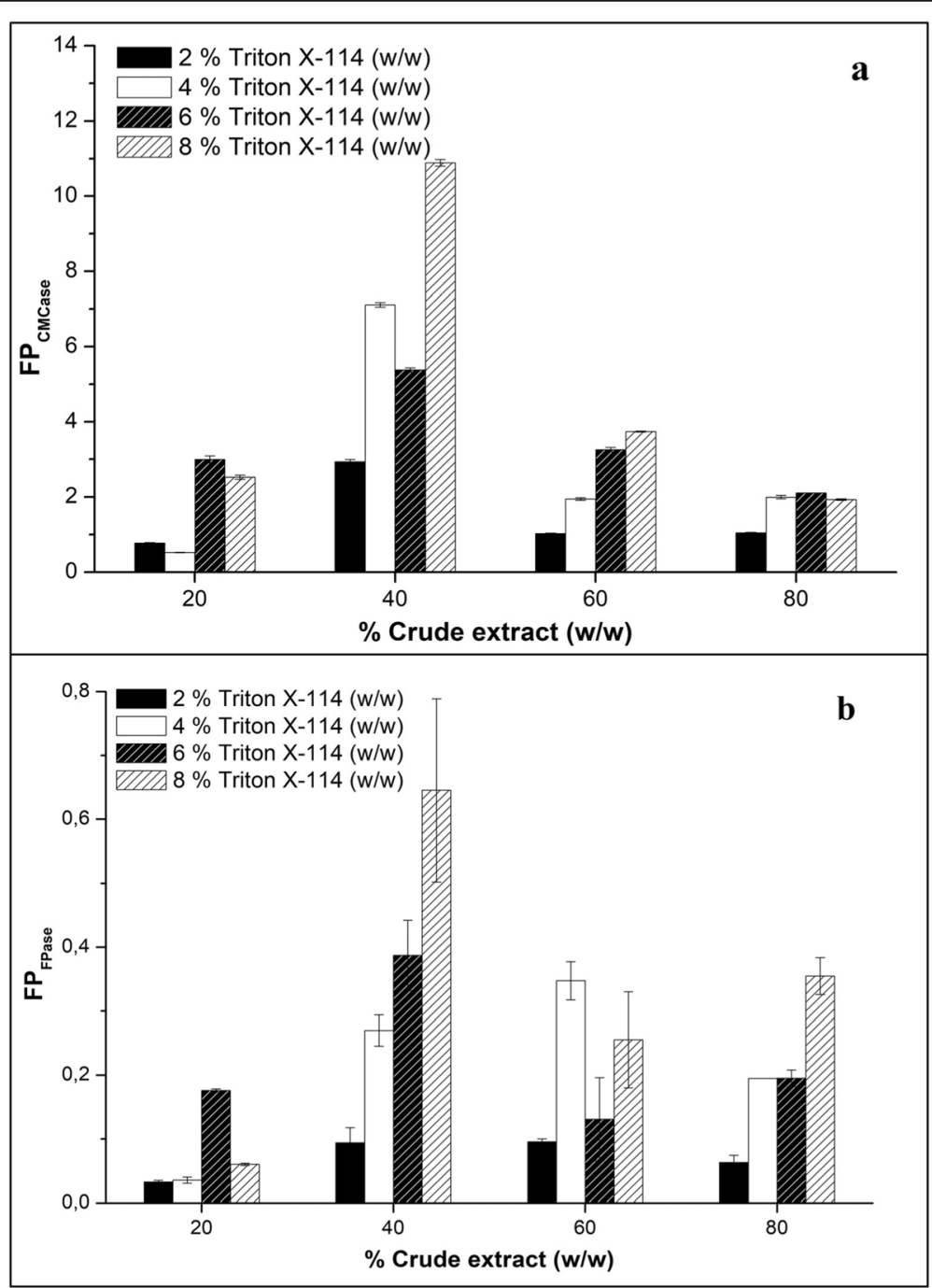

Fig. 5 Purification factor for CMCase (a) and FPase (b) obtained during partitioning in the ATPMS using different Triton X-114 concentrations and changing the crude extract concentration at $55^{\circ} \mathrm{C}$ 
this study, we investigated the influence of the inorganic salts on the partitioning of cellulolytic enzymes produced by the filamentous fungus A. fumigatus CCT 7873 using ATPMS. For these experiments, the temperature and crude extract were $55{ }^{\circ} \mathrm{C}$ and $40 \%(\mathrm{w} /$ $\mathrm{w})$, respectively. These values were chosen since they led to the best results overall, for yield and PF, for both enzymes, as can be seen in Figs. 3, 4, and 5. Thus, the enzyme partitioning was carried out in the presence of the salts $\mathrm{CaCl}_{2}, \mathrm{MgSO}_{4}, \mathrm{MnSO}_{4}$, and $\mathrm{NaCl}$, changing the Triton X-114 concentration from $2 \%(\mathrm{w} / \mathrm{w})$ up to $8 \%$ $(w / w)$, as shown in Figs. 6 and 7. The addition of $\mathrm{CaCl}_{2}$ favored the partition coefficient for both enzymes, as seen in Supplemental Table S3. For instance, a $K$ value of 50 was obtained for ATPMS containing $2 \%(\mathrm{w} / \mathrm{w})$ Triton X114 operating at $55{ }^{\circ} \mathrm{C}$ with $40 \%(\mathrm{w} / \mathrm{w})$ crude extract, while the $K$ value for FPase was 13.5.
Figure 8 shows the SDS-PAGE and the zymogram obtained using an ATPMS consisting of $40 \%(\mathrm{w} / \mathrm{w})$ crude extract operating at $55{ }^{\circ} \mathrm{C}$ using different concentrations of Triton X-114 (2, 4, 6, and 8\% w/w). The crude extract showed at least four bands with molecular masses of 25 , 33, 39, 52, and $70 \mathrm{kDa}$.

\section{Discussion}

The coexistence curve showed that a higher extract concentration led to a lower critical temperature (Tc) for the ATPMS. Additionally, the lowest Tc occurred at $20.4{ }^{\circ} \mathrm{C}$ at a Triton X-114 concentration of $0.5(\mathrm{w} / \mathrm{w})$. An aqueous solution containing the nonionic surfactant Triton X-114 can suffer from macroscopic changes in the phase separation with an increase in temperature, thus forming a micelle-rich phase (bottom phase) and a micelle-poor phase (top phase) (Ramelmeier et al. 1991).

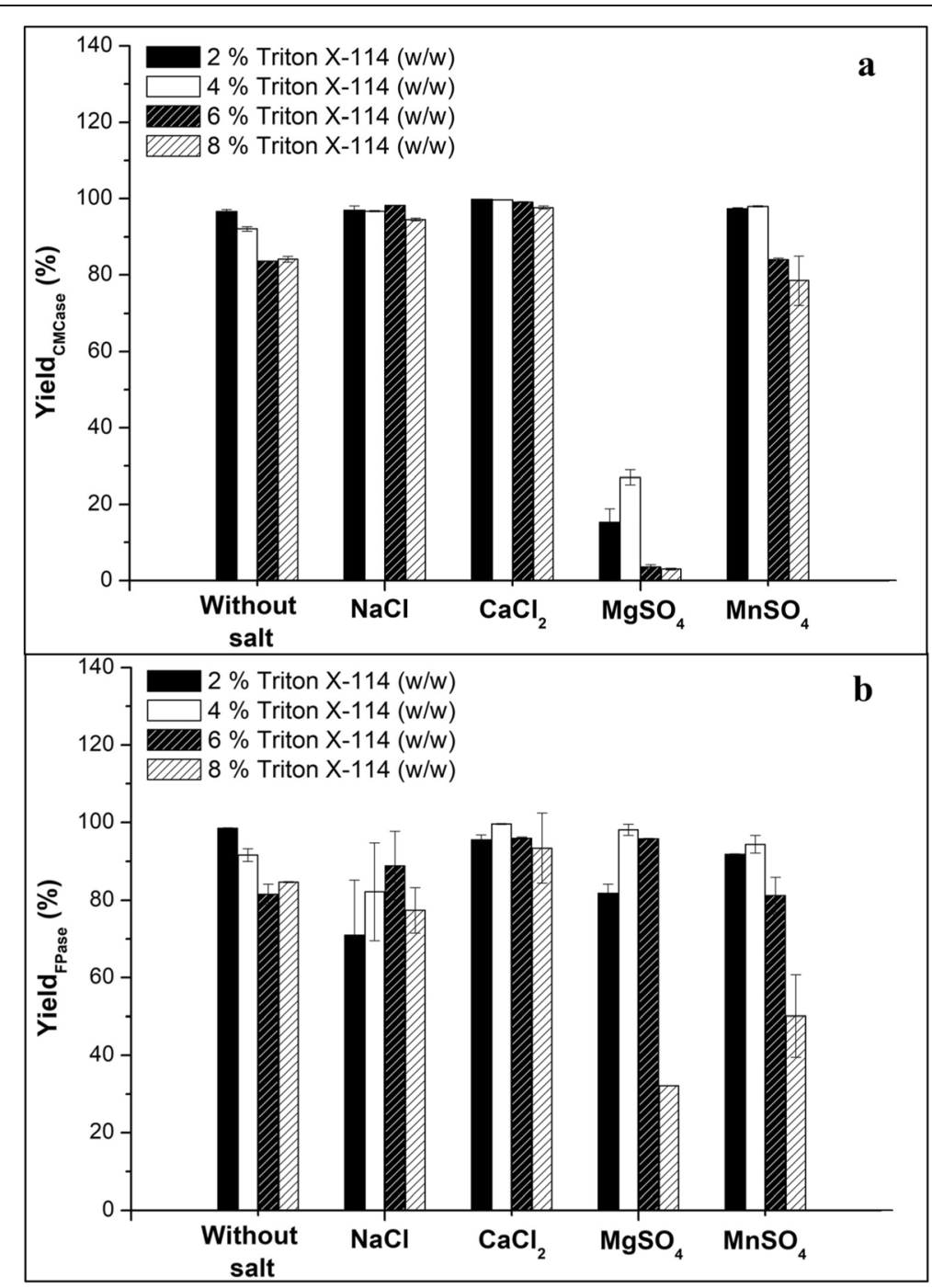

Fig. 6 CMCase (a) and FPase (b) yields obtained during partitioning in the ATPMS using different Triton X-114 concentrations and inorganic salts at $55^{\circ} \mathrm{C}$ and $40 \%$ (w/w) crude extract concentration 


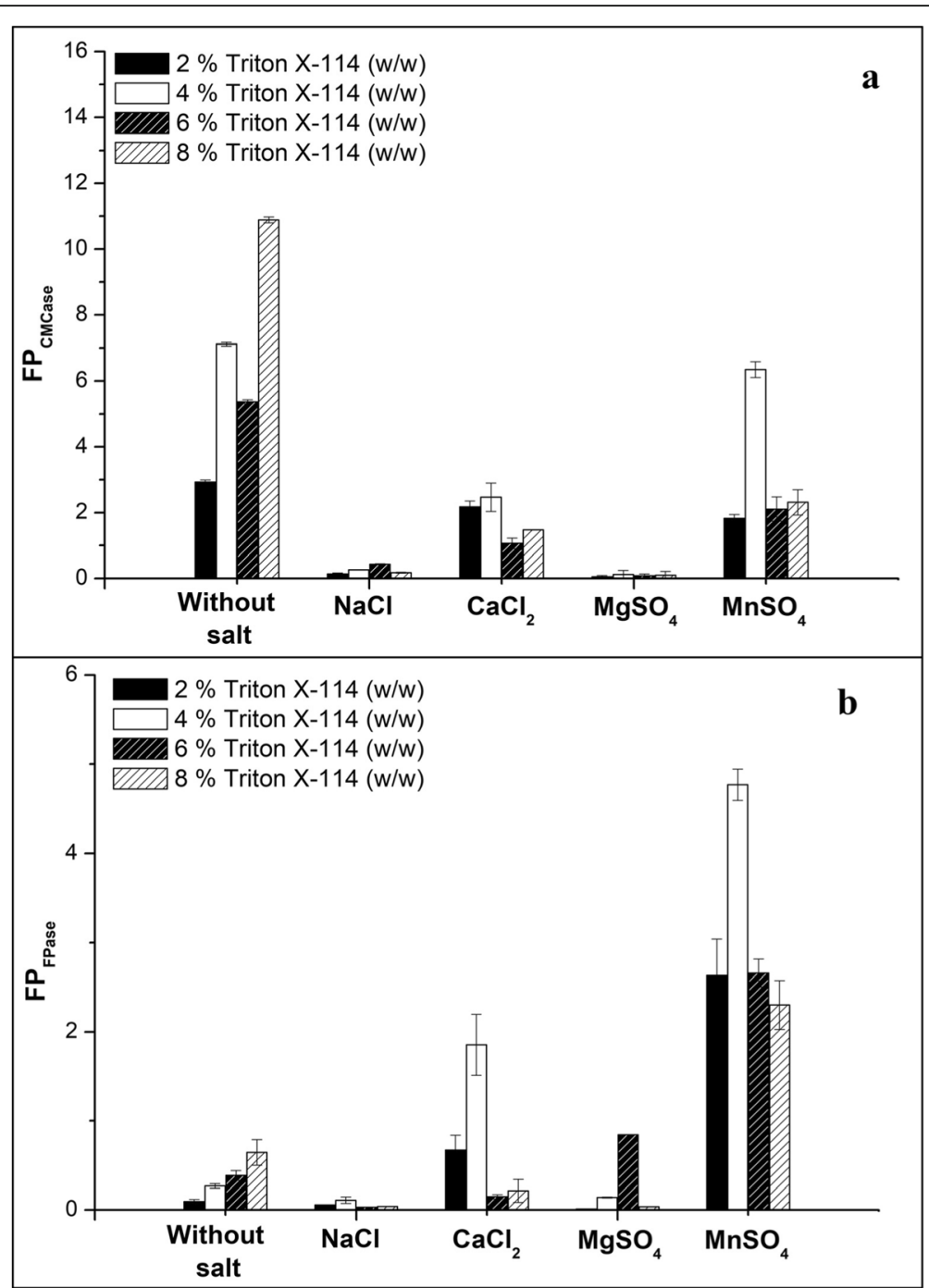

Fig. 7 Purification factor for CMCase (a) and FPase (b) obtained during partitioning in the ATPMS using different Triton X-114 concentrations and inorganic salts at $55^{\circ} \mathrm{C}$ and $40 \%(\mathrm{w} / \mathrm{W})$ crude extract concentration

The structures, shapes, and sizes of the micelles can be altered by changing the system temperature or the surfactant concentration, or by adding salt to the system (Liu et al. 1996). An increase in temperature causes dehydration of the oxyethylene group, which is responsible for the higher polarity region at the surfactant chain, thus promoting phase separation due to the molecule solubility. The cloud point of the system occurs due to monomer surfactant aggregation, causing phase separation (Quina and Hinze 1999).

With regard to the influence of the Triton X-114 concentration and temperature on cellulolytic enzyme partitioning for FPase, the highest value for $K$ was 5.0 and was obtained at $60{ }^{\circ} \mathrm{C}$ with Triton $\mathrm{X}-114$ concentrations of 6 and $8 \%(\mathrm{w} / \mathrm{w})$. Thus, both enzymes preferred the micelle-poor phase. Also, for both enzymes, the yield relied on both the temperature and the surfactant concentration. This effect is more pronounced for FPase; for instance, we observed that when the Triton X-114 concentration was increased from 2 to $8 \%(\mathrm{w} / \mathrm{w})$, the yield for this enzyme increased from about $67 \%$ at $35{ }^{\circ} \mathrm{C}$ to $97.88 \%$ at $60{ }^{\circ} \mathrm{C}$, an increase of approximately $46.09 \%$. A higher $K$ value is important, as in this case the enzyme was being concentrated in the surfactant-poor phase.

Thus, with regard to the influence of the Triton X-114 concentration on the purification factor for CMCase, an increase of almost 19-fold was seen in a system with the same Triton X114 concentration $(8 \%(w / w))$, but operating at $55{ }^{\circ} \mathrm{C}$ instead of $35{ }^{\circ} \mathrm{C}$, as shown in Fig. $5 \mathrm{a}$ and Supplemental Table S1. Therefore, for CMCase, there was a phase change due to the increase in temperature when the system contained Triton X-114 at $8 \%(\mathrm{w} / \mathrm{w})$. This phase change probably occurred due to a preference for the micelle-rich phase (bottom phase) caused 


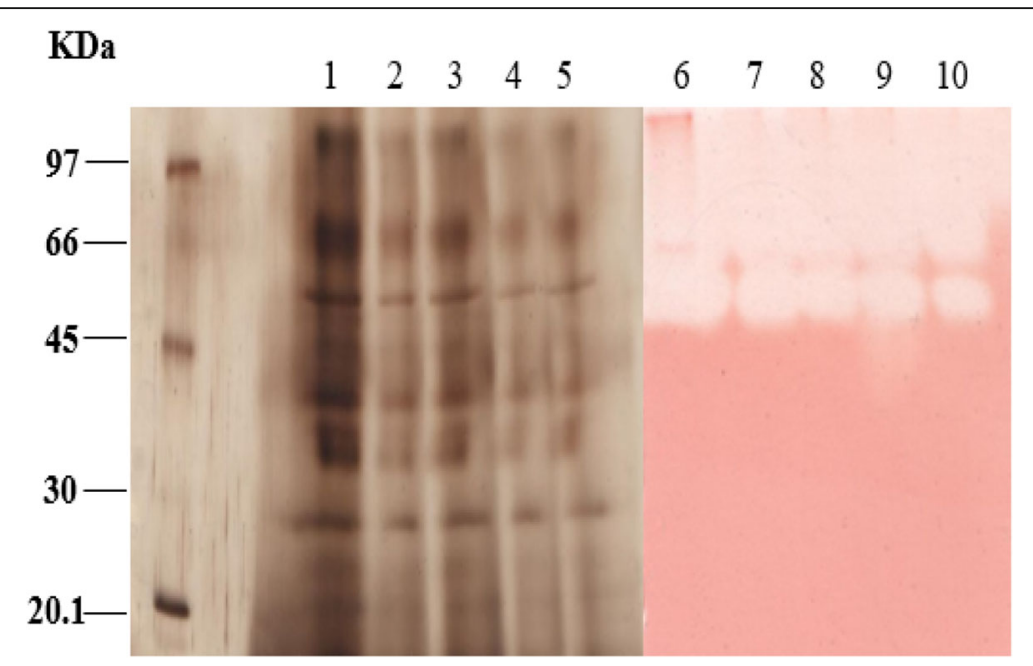

Fig. 8 SDS-PAGE (lanes 1-5) and zymogram (lanes 6-10). 1,6: crude extract; 2,6: 2\% Triton X-114 (w/w); 3,8: 4\% Triton X-114 (w/w); 4,9: 6\% Triton X-114 (w/W); and 5,10: 8\% Triton X-114 (w/w)

by the temperature increase. Thus, it reduced the volume occupied by the hydrophilic enzymes, causing the migration of these enzymes to the top phase. Additionally, as can be seen in Fig. 2, the enzymes were denatured at temperatures above $65{ }^{\circ} \mathrm{C}$. It should be noted that there has not previously been a report using the ATPMS approach to recover and purify cellulases existing in the broth, as we have done in the current study. Vicente et al. (2019) previously combined an aqueous two-phase system (ATPS) and ATPMS based on Pluronic L-35, a thermo-responsive copolymer, in order to selectively separate three model proteins: cytochrome c, ovalbumin, and azocasein.

Considering the influence of the Triton X-114 concentration and crude extract on the FPase yield at a constant temperature of $55{ }^{\circ} \mathrm{C}$ (Fig. $4 \mathrm{~b}$ ), the use of the $20 \%$ $(\mathrm{w} / \mathrm{w})$ crude extract strongly reduced the yield. In this case, a decrease from 65 to $20 \%$ was observed. Compared to CMCase, this reduction was quite small, from 98.5 to $93 \%$. In addition, the use of $40 \%$ (w/w) crude extract was more favorable for CMCase. For FPase, an increase in the crude extract above $40 \%(\mathrm{w} / \mathrm{w})$ did not significantly alter the yield. Thus, greatly increasing the concentration of the crude extract was not effective at improving biomolecule extraction. In this case, it can precipitate the target biomolecule and also influence enzyme partitioning (Malpiedi et al. 2011). Regarding the purification factors for both CMCase and FPase, the former showed a PF value of 10.89 , while the latter showed a higher PF value of 0.65 . For FPases at a temperature of $55{ }^{\circ} \mathrm{C}$, regardless of the Triton X-114 concentration and crude extract used in this study, these enzymes showed a preference for the micelle-rich phase (bottom phase), which could be due to the more hydrophobic features of these enzymes. The results of this study are in accordance with those shown by Jaramillo et al. (2013), which reported $8 \%(\mathrm{w} / \mathrm{w})$ and $20 \%$ concentrated crude extract $(\mathrm{w} / \mathrm{w})$ when extracting pectinases using ATPMS.

With regard to the influence of the Triton X-114 concentration and inorganic salts on cellulolytic enzyme partitioning, it was observed that the addition of $\mathrm{CaCl}_{2}$ favored the partition coefficient for both enzymes, as seen in the Supplemental Table S3. For instance, a $K$ value of 50 was obtained for ATPMS containing $2 \%(\mathrm{w} /$ w) Triton X-114 operating at $55{ }^{\circ} \mathrm{C}$ with $40 \%(\mathrm{w} / \mathrm{w})$ crude extract, while the $K$ value for FPase was 13.5. Also, not only was the $K$ favored but a higher yield was also obtained when this salt was added to the system. Overall, in the presence of $\mathrm{MgSO}_{4}$, a yield of $70 \%$ was obtained for both CMCase and FPase. A lower yield (less than $30 \%$ regardless of the Triton X-114 concentration) was observed for the CMCase. The effect of the ion type on this enzyme partitioning becomes evident when comparing the yields obtained in the presence of $\mathrm{MgSO}_{4}$ with those obtained when $\mathrm{MnSO}_{4}$ is used, as shown in Fig. 6a. Therefore, the use of the latter is better than the former for CMCase yield. Indeed, the use of $\mathrm{MnSO}_{4}$ was more favorable for the yield of CMCase in the micellepoor phase. An inverse relationship was observed for FPase. Thus, the anion size plays a key role in the salting out: the lower the anion the higher its hydration capacity, and since the radii of the $\mathrm{Mn}^{+2}$ is less than that of $\mathrm{Mg}^{+2}$, the former induces the micelle-micelle interaction, thus pushing the CMCase to the upper phase and improving $K, Y$, and FP. Additionally, in presence of $\mathrm{NaCl}$ and $\mathrm{MgSO}_{4}, \mathrm{CMCase}$ showed a PF less than 1.0, regardless of the Triton X-114 concentration used, as seen in Fig. 7a. The salt presence was not at all beneficial for the PF of CMCase, mainly due to the salting-out effect, since 
the use of an ATPMS composed by Triton X-114 at $8 \%$ (w/w) operating at $55{ }^{\circ} \mathrm{C}$ with $40 \%(\mathrm{w} / \mathrm{w})$ crude extract but without salt addition resulted in a PF of 10.89. For the FPase, the addition of $5 \%(\mathrm{w} / \mathrm{w}) \mathrm{MnSO}_{4}$ resulted in a PF value of approximately 5.0, as can be seen in Fig. 7b.

The differences in biomolecule partitioning, mainly of enzymes and proteins, were that the ions could exhibit very different behaviors when partitioning between the two phases (Costa et al. 1998, Harris et al. 1998, Umakoshi et al. 1996). The addition of salt, even at millimolar concentrations, can influence the partitioning of the charged biomolecules. Even though the salts can be partitioned almost equally between the phases, it is possible for differences to arise in the partition coefficients of different ion species. This can create an electric potential difference between the phases, subsequently influencing the partitioning of charged biomolecules (Sarubbo et al. 2000). As shown in the zymogram (Fig. 8), the crude extract showed at least four bands with molecular masses of $25,33,39,52$, and $70 \mathrm{kDa}$. The range of the molecular masses of the proteins in the present study is similar to the range reported by Morozova et al. (2010). Thus, based on the results of the present study, an integrative technique (Araújo et al. 2016; Araújo Padilha et al. 2017; Glyk et al. 2015; Wanderley et al. 2017) such as ATPMS (Amid et al. 2013) can be successful at partitioning cellulases. Overall, the highest values obtained for the yield and PF show that ATPMS is an interesting technique for recovering and purifying cellulolytic enzymes.

\section{Supplementary information}

Supplementary information accompanies this paper at https://doi.org/10 1186/s13213-020-01573-w.

Additional file 1: Table S1. Partition coefficient, yield (\%) and purification factor for the CMCase and FPase using ATPMS composed by Triton X-114 (2, 4, 6 and 8\% (w/W)) at different temperatures at 40\% (w/ w) crude extract. Table S2. Partition coefficient, yield (\%) and purification factor for the CMCase and FPase using ATPMS composed by Triton X-114 $(2,4,6$ and $8 \%(\mathrm{w} / \mathrm{w}))$ at different crude extract, keeping the temperature at $55{ }^{\circ} \mathrm{C}$. Table S3. Partition coefficient, yield (\%) and purification factor for the CMCase and FPase using ATPMS composed by Triton X-114 (2, 4 6 and $8 \%(w / w))$ at different inorganic salts. The crude extract concentration was $40 \%(\mathrm{w} / \mathrm{W})$ and the temperature was $55^{\circ} \mathrm{C}$.

\section{Authors' contributions}

The author(s) read and approved the final manuscript.

\section{Funding}

This study was financially supported by CAPES and the Brazilian National Council of Research (CNPq) (Grant 407684/2013-1).

\section{Ethics approval and consent to participate}

This article does not contain studies with human participants or animals performed by any of the authors. Informed consent was obtained from all individual participants included in the study.

\section{Competing interests}

The authors declare that they have no conflicts of interest.
Received: 9 August 2019 Accepted: 23 April 2020

Published online: 04 May 2020

\section{References}

Amid M, Manap MYA, Shuhaimi M (2013) Purification of a novel protease enzyme from kesinai plant (Streblus asper) leaves using a surfactant-salt aqueous micellar two-phase system: a potential low cost source of enzyme and purification method. Eur Food Res Techn 237:601-608. https://doi.org/10. 1007/s00217-013-2037-3

Araújo NK, Pimentel VC, Silvam NMP, Padilha CEA, Macedo GR, Santos ES (2016) Recovery and purification of chitosanase produced by using expanded bed adsorption and central composite design. J Sep Sci. 39:709-716. https://doi. org/10.1002/jssc.201500900

Araújo Padilha CE, Oliveira Júnior SD, Souza DFS, Araújo JO, Macedo GR, Santos ES (2017) Baker's yeast invertase purification using aqueous two phase system-modeling and optimization with PCA/LS-SVM. Food Biopr Proc. 101: 157-165. https://doi.org/10.1016/j.fbp.2016.11.004

Bradford MM (1976) A rapid and sensitive method for the quantification of microgram quantities of protein utilizing the principle of protein-dye binding. Anal Biochem. 72:248-254. https://doi.org/10.1016/00032697(76)90527-3

Castilho LR, Polato CMS, Baruque EA, Sant'anna GL Jr, Freire D (2000) Economic analysis of lipase production by Penicillium restrictum in solid-state and submerged fermentations. Biochem Eng J. 4:239-247. https://doi.org/10. 1016/S1369-703X(99)00052-2

Chandra Kalra A, Sharma PK, Kumar H, Sangwan RS (2010) Optimization of cellulases production by Trichoderma citrinoviride on marc of Artemisia annua and its application for bioconversion process. Biom Bioenergy. 34:805-811. https://doi.org/10.1016/j.biombioe.2010.01.024

Coelho MAZ, Leite SGF, Rosa MF, Furtado AAL (2001) Aproveitamento de resíduos agroindustriais: produção de enzimas a partir da casca de coco. Boletim Ceppa. 19:33-42

Costa SA, Pessoa A Jr, Roberto IC (1998) Xylanase recovery by aqueous two phase systems using experimental design. App Biochem Biotech. 70:629-639. https://doi.org/10.1007/BF02920174

Gan Q, Allen SJ, Taylor G (2003) Kinetic dynamics in heterogeneous enzymatic hydrolysis of cellulose: an overview, an experimental study and mathematical modelling. Process Biochem. 38:1003-1018. https://doi.org/10.1016/S00329592(02)00220-0

Ghose TK (1987) Measurement of cellulase activities. Pure App Chem. 59:257-268. https://doi.org/10.1351/pac198759020257

Glyk A, Scheper T, Beutel S (2015) PEG-salt aqueous two-phase systems: an attractive and versatile liquid-liquid extraction technology for the downstream processing of proteins and enzymes. Appl Microbiol Biotech. 99: 6599-6616. https://doi.org/10.1007/s00253-015-6779-7

Harris P, Wright G, Andrews AT, Pyle DL, Asenjo JA (1998) The application of aqueous two-phase partitioning to the purification of proteins from transgenic sheep milk. Biosep. 9:823-826. https://doi.org/10.1023/A: 1007908703773

Jaramillo PMD, Gomes HAR, Siqueira FG, Homem-de-Mello M, Ferreira Filho EX, Magalhães PO (2013) Liquid-liquid extraction of pectinase produced by Aspergillus oryzae using aqueous two-phase micellar system. Sep Pur Technol. 120:452-457. https://doi.org/10.1016/j.seppur.2013.09.020

Laemmli UK (1970) Cleavage of structural proteins during the assembly of the head of bacteriophage T4. Nature. 227:680-685. https://doi.org/10.1038/ $227680 \mathrm{a} 0$

Liu CL, Kamei DT, King JA, Wang DIC, Blankschtein D (1998) Separation of proteins and viruses using two-phase aqueous micellar systems. J Chrom B: Biomed Sci App. 711:127-138. https://doi.org/10.1016/S0378-4347(98)00013-9

Liu CL, Nikas YJ, Blankschtein D (1996) Novel bioseparations using two-phase aqueous micellar systems. Biotechnol Bioeng. 52:185-192

Machado AV, Oliveira EL, Santos ES, Oliveira JA (2010) Cashew-nut (Annacardium occidentale L.) drying study using a solar dryer with direct radiation. Inf Tecnol. 21:27-33

Malpiedi LP, Picó GA, Nerli BB (2011) Studies of protein partition in nonconventional aqueous two-phase systems as method to purify trypsinogen and alpha-chymotrypsinogen from bovine pancreas. Sep Pur Technol. 78:9196. https://doi.org/10.1016/j.seppur.2011.01.026

McCreath GE, Chase HA, Owen R, Lowe CR (1995) Expanded bed affinity chromatography of dehydrogenases from bakers-yeast using dye-ligand 
perfluoropolymer supports. Biotechnol Bioeng. 48:341-354. https://doi.org/10. 1002/bit.260480407

Miller GL (1959) Use of dinitrosalicylic acid reagent for determination of reducing sugar. Anal Chem. 31:426-428. https://doi.org/10.1021/ac60147a030

Morozova W, Gusakov AV, Andrianov RM, Pravilnikov AG, Osipov DO, Sinitsyn AP (2010) Cellulases of Penicillium verruculosum. Biotechnol J. 5:871-880. https:// doi.org/10.1002/biot.201000050

Oliveira SD, Padilha CEA, Asevedo EA, Pimentel VC, Araújo FR, Macedo GR, Santos ES (2018) Utilization of agroindustrial residues for producing celulases by Aspergillus fumigatus on Semi-Solid Fermentation. J Env Chem Eng. 6(1):937944. https://doi.org/10.1016/j.jece.2017.12.038

Ooi CW, Tan CP, Hii SL, Ariff A, Ibrahim S, Ling TC (2011) Primary recovery of lipase derived from Burkholderia sp. ST8 with aqueous micellar two-phase system. Proc Biochem. 46:1846-1852. https://doi.org/10.1016/j.procbio.2011. 06.014

Quina FH, Hinze WWL (1999) Surfactant-mediated cloud point extractions: an environmentally benign alternative separation approach. Ind Eng Chem. 38: 4150-4168. https://doi.org/10.1021/ie980389n

Ramelmeier RA, Terstappen GC, Kula MR (1991) The partitioning of cholesterol oxidase in Triton X-114 based aqueous two-phases systems. Biosep. 2:315-324

Rangel-yagui CO, Pessoa-Jr A, Blankschtein D (2004) Two-phase aqueous micellar systems: an alternative method for protein purification. Braz J Chem Eng. 21: 531-544. https://doi.org/10.1590/50104-66322004000400003

Ruiz HA, Rodriguez-Jasso RM, Rodriguez R, Contreras-Esquivel JC, Aguilar CN (2012) Pectinase production from lemon peel pomace as support and carbon source in solid-state fermentation column-tray bioreactor. Biochem Eng J. 65:90-95. https://doi.org/10.1016/j.bej.2012.03.007

Sarubbo LA, Oliveira LA, Porto ALF, Duarte HS, Carneiroleão AMA, Lima Filho JL, Campos-Takaki GM, Tambourgi EB (2000) New aqueous two-phase system based on cashew-nut tree gum and poly (ethylene glycol). J Chromatrog Biomed Sci App. 743(1-2):79-84

Sousa Júnior FC, Padilha CEA, Chibério AS, Ribeiro VT, Martins DRA, Oliveira JA, Macedo GR, Santos ES (2016) Modeling and simulation of breakthrough curves of recombinant 503 antigen using immobilized metal affinity expanded bed adsorption chromatography. Sep Pur Technol. 164:34-40. https://doi.org/10.1016/j.seppur.2016.03.019

Sousa LD, Chundawat SPS, Balan V, Dale BE (2009) 'Cradle-to-grave' assessment of existing lignocellulose pretreatment technologies. Curr. Opin. Biotech. 20 339-347. https://doi.org/10.1016/i.copbio.2009.05.003

Takenaka A, Colin GD, Kudo H, Itabashi H, Cheng K (1999) Molecular cloning, expression, and characterization of an endo- $\beta$-1,4-glucanase cDNA from Epidinium caudatum. The J Gener App Microbiol. 45:57-61. https://doi.org/10. 2323/jgam.45.57

Umakoshi H, Yano K, Kuloi R, Komaswa I (1996) Exative cultivation of recombinant Escherichia coli using aqueous two-phase systems for production and separation of intracellular heat shock proteins. Biotechnol Prog. 12:51-56. https://doi.org/10.1021/bp9500472

Urbanszki K, SzakacS G, Tengerdy RP (2000) Standardization of the filter paper activity assay for solid substrate fermentation. Biotechnol Lett. 22:65-69. https://doi.org/10.1023/A:1005654514980

Vicente FA, Santos JHPM, Pereira IMM, Gonçalves CVM, Dias ACRV, Countinho JAP, Ventira SPM (2019) Integration of aqueous (micellar) to phase systems on proteins separation. BMC Chem Eng. 1(4):1-12. https://doi.org/10.1086/ s42480-019-0004-x

Wanderley MCA, Duarte Neto JMW, Albuquerque WWC, Marques DAV, Lima CA, Silvério SIC, Lima Filho JL, Teixeira JAC, Porto ALF (2017) Purification and characterization of a collagenase from Penicillium sp UCP 1286 by polyethylene glycol-phosphate aqueous two-phase system. Prot Expr Pur. 133:8-14. https://doi.org/10.1016/j.pep.2017.02.010

Wang X, Wei X, Liu J, Sun D, Du P, Ping A (2013) Study on the aqueous twophase systems composed of surfactant, ionic liquid and water. Fluid Phase Equilib. 347:1-7. https://doi.org/10.1016/j.fluid.2013.03.004

Watanabe H, Tanaka H (1978) A non-ionic surfactant as a new solvent for liquidliquid extraction of zinc (II) with 1-(2-pyridylazo)-2-naphthol. Talanta. 25:585589. https://doi.org/10.1016/0039-9140(78)80151-9

\section{Publisher's Note}

Springer Nature remains neutral with regard to jurisdictional claims in published maps and institutional affiliations. 